\title{
TINJAUAN ATAS PERKEMBANGAN PENDIDIKAN KEWARGANEGARAAN DALAM RUMPUN ILMU SOSIAL
}

\author{
Nastiti Mufidah \\ Dosen Jurusan Tadris Ilmu Pengetahuan Sosial, Fakultas Tarbiyah dan Ilmu Keguruan, Institut \\ Agama Islam Negeri Ponorogo, Jl. Pramuka 156, Po. Box 116 Ponorogo 63471, \\ nastiti@iainponorogo.ac.id
}

\begin{abstract}
ABSTRAK
Perkembangan Pendidikan Kewarganegaraan tidak terlepas dari berbagai keilmuan lain yang menunjangnya, diantaranya berbagai keilmuan yang berasal dari dari rumpun ilmu sosial. Artikel ini ditulis bertujuan untuk menyingkap perkembangan Pendidikan Kewarganegaraan dalam rumpun ilmu sosial khususnya ilmu sosiologi dan sejarah, maupun ilmu sosial humaniora yakni ilmu politik dan ilmu hukum. Perkembangan Pendidikan Kewarganegaraan terkait dengan berbagai rumpun ilmu sosial dapat dilihat dari hasil penelusuran yang dilakukan oleh peneliti berdasarkan realita serta teoriteori dasar dari para ahli. Penelitian ini berupa penelitian kualitatif dengan studi literasi yang menghasilkan kesimpulan bahwa dalam perkembangannya Pendidikan Kewarganegaraan memang tidaklah dapat terlepas dari berbagai ilmu yang berada dalam rumpun Ilmu Sosial sebagaimana mata kuliah dalam Ilmu Sosial diajarkan sebagai pewarisan dari nilai Kewarganegaraan (Citizenship Transmission). Ilmu Sosial sebagai pewarisan nilai-nilai kewarganegaraan mempunyai tujuan utama dalam mempersiapkan anak didik menjadi warga negara yang baik dengan menggunakan nilai dan budaya bangsa sebagai landasan untuk mengembangkan bangsanya.
\end{abstract}

Kata Kunci: Pendidikan Kewarganegaraan, Ilmu Sosial

\begin{abstract}
The development of Citizenship Education is inseparable from the various other sciences that support it, including various sciences that come from the social sciences family. This article was written aimed at exposing the development of Citizenship Education in the social sciences, especially sociology and history, as well as the social sciences of humanities, namely political science and law. The development of Citizenship Education related to various social science families can be seen from the results of searches conducted by researchers based on reality and basic theories from experts. This research is in the form of a qualitative research with a literacy study which results in the conclusion that in its development Citizenship Education is indeed inseparable from the various sciences within the Social Sciences family as courses in Social Sciences are taught as inheritance from the Citizenship Transmission value. Social Sciences as the inheritance of the values of citizenship have the main objective in preparing students to become good citizens by using the values and culture of the nation as a foundation for developing their nation.
\end{abstract}

Keywords: Citizenship Education, Social Sciences

\section{PENDAHULUAN}

Pendidikan Kewarganegaraan adalah salah satu mata kuliah yang difokuskan pada pembentukan warga negara yang memahami dan mampu melaksanakan hak-hak dan kewajibannya untuk menjadi warga negara yang baik, cerdas, terampil, dan berkarakter layaknya yang diamanatkan oleh Pancasila dan UUD 1945. Pendidikan Kewarganegaraan membahas berbagai aspek dalam kehidupan, diantaranya membahas terkait dengan 
pembentukan diri yang beragam, baik dari segi agama, sosial kultural, bahasa, usia, serta suku bangsa.

Berdasarkan pembahasan yang tertuang dalam mata kuliah Pendidikan Kewarganegaraan tersebut, maka sangatlah sesuai jika kita mengatakan bahwa substansi dari Pendidikan Kewarganegaraan di perguruan tinggi bertujuan untuk memantapkan serta membekali para mahasiswa di Perguruan Tinggi dengan berbagai pengetahuan serta pengetahuan dasar terkait dengan hak dan kewajiban seorang warga negara. Dalam kata lain kemampuan dasar yang diharapkan yakni mahasiswa mampu menerapkan nilai-nilai tersebut dalam kehidupan sehari-hari diantaranya berpikir kritis, memiliki kepribadian yang mantap, bersikap etis, rasional, estetis, dinamis, demokratis serta berwawasan luas. Substansi dari pendidikan Kewarganegaraan tersebut sesuai dengan yang terumus di dalam Kep. Dirjen DIKTI No.43/DIKTI/Kep/2006 ${ }^{1}$.

Terkait dengan substansi tersebut Winataputra ${ }^{2}$ mengemukakan bahwa dalam kaitannya secara holistic pendidikan kewarganegaraan bertujuan agar setiap warga Negara muda (young citizens) memiliki rasa kebangsaan dan cinta tanah air dalam konteks nilai dan moral Pancasila, nilai dan norma Undang-Undang Dasar Negara Republik Indonesia Tahun 1945, nilai dan komitmen Bhinneka tunggal Ika, dan komitmen bernegara kesatuan Republik Indonesia. Dalam kata lain dapat dikatakan bahwa secara sadar dan terencana peserta didik sesuai dengan perkembangan psikologis dan konteks kehidupannya secara sistemik difasilitasi untuk belajar berkehidupan demokrasi secara utuh, yakni belajar tentang demokrasi (learning about democracy), belajar dalam iklim dan melalui proses demokrasi (learning through democracy), dan belajar untuk membangun demokrasi (learning for democracy).

Selain bertujuan untuk mencetak para young citizens, Pendidikan Kewarganegaraan juga dapat dipahami sebagai salah satu jawaban untuk mencetak kader-kader bangsa yang memiliki pemahaman terkait dengan wawasan kebangsaan dan juga semangat nasionalisme dalam rangka untuk memecahkan persoalan kebangsaan yang semakin kompleks. Sehingga dalam kata lain dapat disimpulkan bahwa melalui pendidikan kewarganegaraan, diharapkan warga negara Republik Indonesia mampu menganalisis, memahami dan menjawab masalahmasalah yang dihadapi maupun yang kemungkinan akan dihadapi oleh masyarakat, bangsa dan negaranya secara berkesinambungan dan konisten dalam mewujudkan cita-cita dan tujuan nasional.

Disamping itu Pendidikan Kewarganegaraan yang merupakan salah satu bidang kajian dalam konteks pendidikan nasional juga memiliki peran strategis untuk meningkatkan kembali wawasan kebangsaan dan semangat nasionalisme mahasiswa. Oleh sebab itu maka guna memperkuat peran Pendidikan Kewarganegaraan, pemerintah mewajibkan Pendidikan Kewarganegaraan diberikan pada setiap satuan pendidikan termasuk perguruan tinggi sebagaimana termuat dalam Undang-undang ${ }^{3}$. Berdasarkan perundang-undangan tersebut

\footnotetext{
${ }^{1}$ Undang-Undang No. 20 Tahun 2003 tentang Sistem Pendidikan Nasional Pasal 37 ayat (1) huruf a dan Pasal ayat (2) huruf b.

${ }^{2}$ Winataputra, U.S. Diskursus Aktual Tentang Paradigma Pendidikan Kewarganegaraan (PKn) Dalam Konteks Kurikulum 2013, Bahan Diskusi dalam Semnas PKn-AP3KnI, 2014.

3 ibid
} 
maka dapat dipahami bahwa negara bertanggung jawab untuk mempersiapkan generasi muda/mahasiswa yang memiliki wawasan kebangsaan yang tinggi dan juga memiliki semangat nasionalisme dalam kehidupan berbangsa dan bernegara. Wawasan kebangsaan yang diharapkan untuk dimiliki oleh para mahasiswa harus belandaskan pada suatu realitas yang dihadapi, bahwa mahasiswa adalah sebagai generasi bangsa yang harus memiliki visi intelektual, religius, berkeadaban, berkemanusiaan dan cinta tanah air dan bangsanya.

Adanya mata kuliah Pendidikan Kewarganegaraan juga diharapkan mampu menjadi oase yang menyediakan air segar dalam membantu mahasiswa memantapkan kepribadiannya, agar secara konsisten mampu mewujudkan nilai-nilai dasar Pancasila, rasa kebangsaan dan cinta tanah air dalam menerapkan, menguasai dan mengembangkan ilmu pengetahuan, teknologi dan seni dengan rasa tanggung jawab dan bermoral. Disamping itu mahasiswa juga diharapkan mampu untuk menjaga dan meneruskan cita-cita pembangunan bangsa dengan sungguh-sungguh mencintai bangsanya sendiri, dengan tidak membeda-bedakan setiap suku, ras, maupun agama yang mendiami di bumi pertiwi Indonesia. Dengan wawasan kebangsaan dan juga semangat nasionalisme maka hal ini diharapkan agar kita dapat menjaga keutuhan Negara Kesatuan Negara Indonesia agar tidak terpecah belah.

Dengan melihat berbagai realita serta berbagai peraturan perundang-undangan maupun pendapat dari para ahli terkait dengan tujuan dari Pendidikan Kewarganegaraan tersebut maka tidaklah menutup kemungkinan bahwa Pendidikan Kewarganegaraan memiliki keterkaitan dengan rumpun keilmuan terutama dalam rumpun ilmu sosial. Sifat Pendidikan Kewarganegaraan yang mencakup berbagai aspek kehidupan membuatnya saling berkaitan dengan ilmu yang satu dan ilmu yang lainnya. Berdasarkan keterkaitan tersebut maka studi ini dilakukan dengan tujuan untuk mengetahui gambaran terkait dengan perkembangan Pendidikan Kewarganegaraan jika dikatkan dengan berbagai keilmuan dalam rumpun ilmu sosial diantaranya dengan ilmu sosiologi, sejarah serta ilmu politik dan hukum. Dalam mencapai tujuan dari penelitian tersebut maka analisis dalam studi ini ditujukan untuk menjawab pertanyaan tekait dengan bagaimanakah perkembangan pendidikan kewarganegaraan terkait dengan rumpun ilmu sosial lain terutama dengan ilmu sosiologi, sejarah serta ilmu politik dan hukum.

\section{METODE PENELITIAN}

Metode penelitain kualitatif digunakan dalam penelitian ini. Metode tersebut digunakan berdasarkan rumusan masalah yang mengharuskan peneliti untuk melakukan aktifitas eksplorasi untuk menjelaskan permasalah yang telah menjadi fokus permasalahan dalam penelitian ini. Dengan menggunakan studi dokumentasi maka data dikumpulkan dengan cara menghimpun dan menganalisis dokumen-dokumen yang selanjutnya dianalisis oleh peneliti. Penelitian ini menganalisis dokumen-dokumen yang berasal dari dokumen tertulis, hasil karya, maupun elektronik. Ruang lingkup dalam penelitian ini terbatas hanya pada perkembangan pada pembelajaran Pendidikan Kewarganegaraan di lingkup perguraun tinggi, serta keterkaitannya dengan pembelajaran dalam rumpun keilmuan sosial terutama ilmu sosiologi, sejarah serta ilmu politik dan hukum. Jenis dan sumber data dalam penelian ini diperoleh bedasarkan pendapat dari para ahli dan berdasarkan pada penelitain sebelumnya terkait dengan Pendidikan Kewarganegaraan dan ilmu sosial terutama ilmu sosiologi, sejarah serta ilmu politik dan hukum. 


\section{HASIL DAN PEMBAHASAN}

Dalam bahasan terkait dengan perkembangan Pendidikan kewarganegaraan, peneliti lebih dulu mengutip ungkapan yang dikemukakan oleh Wahab dan Sapriya ${ }^{4}$ dimana yang disebut sebagai warga negara yang baik adalah warga negara yang memahami dan mampu melaksanakan dengan baik hak-hak dan kewajibannya sebagai individu, warga negara yang memiliki kepekaan dan tanggung jawab sosial, mampu memecahkan masalah-masalahnya sendiri dan juga masalah-masalah kemasyarakatan secara cerdas sesuai dengan fungsi dan perannya (socially sensitive, socially responsible, dan socially inteligence), memiliki sikap disiplin pribadi, mampu berpikir kritis kreatif, dan inovatis agar dicapai kualitas pribadi dan perilaku warga negara dan warga masyarakat yang baik (socio civic behavior dan desirable personal qualities).

Menjadi seorang warganegara yang baik sesuai dengan ungkapan tersebut seyogyanya dapat dimulai dengan pendidikan. Karena menurut Undang-undang ${ }^{5}$ pendidikan adalah upaya masyarakat dan pemerintah untuk menjamin kelangsungan hidup warganya dan generasi penerusnya, secara bermakna dan mampu mengantisipasi hari depan mereka yang senantiasa terkait dengan konteks budaya, bangsa, negara dan hubungan internasionalnya. Pengertian pendidikan menurut Undang-undang Sisdiknas tersebut memiliki arti bahwa pendidikan adalah usaha sadar yang bertujuan untuk mengembangkan potensi peserta didik sehingga mencapai kedewasaan.

Adapun Djahiri ${ }^{6}$ menjelaskan mengenai pengertian Pendidikan Kewarganegaraan yakni, PKn atau civic education adalah program pendidikan atau pembelajaran yang secara programmatik-prosedural berupaya memanusiakan (humanizing) dan membudayakan (civilizing) serta memberdayakan (empowering) menjadi warga negara yang baik sebagaimana tuntutan keharusan/yuridis konstitusional bangsa atau negara yang bersangkutan. Pengertian dari Pendidikan Kewarganegaraan yang tersebut memiliki makna bahwa Pendidikan Kewarganegaraan merupakan pendidikan yang berupaya untuk menjadikan manusia seutuhnya, baik dalam hal kepribadiannya, budaya, dan perannya untuk suatu bangsa dan negara. Berkenaan dengan Pendidikan Kewarganegaraan, Branson ${ }^{7}$ juga menjelaskan tujuan dari Pendidikan Kewarganegaraan adalah partisipasi yang bermutu dan bertanggungjawab dalam kehidupan politik dan masyarakat baik ditingkat lokal, negara bagian, dan nasional. Partisipasi semacam itu memerlukan:

1) Penguasaan terhadap pengetahuan dan pemahaman tertentu,

2) Pengembangan kemampuan intelektual dan partisipatoris,

3) Pengembangan karakter atau sikap mental tertentu,

4) Komitmen yang benar terhadap nilai dan prinsip fundamental demokrasi konstitusional Amerika.

\footnotetext{
${ }^{4}$ Abdul Aziz Wahab dan Sapriya, Teori dan Landasan Pendidikan Kewarganegaraan (Bandung: Alfabeta, 2011), hlm.311-312

${ }^{5}$ Undang-undang No.20 Tahun 2003 tentang Sistem Pendidikan Nasional Pasal 1 ayat (1)

${ }^{6}$ Achmad Kosasih Djahiri, Esensi Pendidikan Nilai-Moral dan PKN di Era Globalisasi (Bandung:Lab. PKn UPI, 2006), hlm.9

${ }^{7}$ Branson, Belajar "Civic Education" dari Amerika. Terjemahan Syarifudin dkk. (Yogyakarta: LKIS, 1999), hlm.7
} 
Selain itu, tujuan dari Pendidikan Kewarganegaraan di perguruan tinggi juga dirumuskan dalam visi, misi dan kompetensi yang tercantum dalam Kep. Dirjen DIKTI No.43/DIKTI/Kep/2006 ${ }^{8}$. Berdasarkan yang tertuang dalam Surat Keputusan Dirjen Dikti tersebut dapat kita ketahui bahwa substansi pendidikan kewarganegaraan di Perguruan Tinggi, pada hakikatnya yaitu untuk membekali dan memantapkan mahasiswa dengan pengetahuan dan kemampuan dasar hubungan warga negara Indonesia yang Pancasilais dengan negara dan sesama warganegara. Dengan kemampuan dasar diharapkan mahasiswa mampu menerapkan nilai-nilai tersebut dalam kehidupan sehari-hari serta memiliki kepribadian yang mantap, berpikir kritis, bersikap rasional, etis, estetis, dan dinamis, berpandangan luas, bersikap demokratis dan berkeadaban. Berdasarkan tujuan Pendidikan Kewarganegaraan yang dijelaskan oleh berbagai ahli dan sumber tersebut memperlihatkan bahwa hal yang diharapkan dari Pendidikan Kewarganegaraan bukan hanya kemampuan seorang warganegara dalam hal intelektual saja, melainkan mencakup berbagai macam aspek sosial. Dalam mengembangkan Pendidikan Kewarganegaraan, terdapat beberapa ilmu sosial yang hubungannya seperti ilmu sosiologi, sejarah serta ilmu politik dan hukum.

Sebelum membahas terkait dengan perkembangan Pendidikan Kewarganegaraan terkait dengan ilmu sosiologi, langkah yang harus lebih dulu diambil yakni memahami apakah yang yang dimaksud dan menjadi ruang lingkup kajian yang dibahas adalam ilmu sosiologi. Menurut para ahli ilmu sosiologi adalah ilmu yang mempelajari masyarakat dan hubungan antar manusia di dalamnya, serta ilmu yang menjelaskan terkait dengan hubungan antara manusia dalam kelompok-kelompok ${ }^{9}$. Ilmu yang memuat penjelasan terkait dengan struktur-struktur dan proses-proses kemasyarakatan yang bersifat stabil, maupun ilmu yang mengatur kehidupan manusia dalam hubungan kelompok, serta sifat dan perubahan lembagalembaga dan ide-ide sosial ${ }^{10}$. Berdasarkan berbagai pendapat dari para ahli tersebut maka dapatlah diambil kesimpulan singkat bahwa sosiologi merupakan ilmu yang mempelajari hubungan antara manusia di dalam masyarakat.

Jika keilmuan sosiologi merupakan keilmuan yang bertujuan untuk mempelajari hubungan antar manusia di dalam masyarakat, maka perkembangan keilmuan Pendidikan Kewarganegaraan sangatlah berhubungan dengan keilmuan sosiologi. Dimana telah kita ketahui bahwa Pendidikan Kewarganegaraan mempelajari mengenai warga masyarakat (rakyat) yang mana rakyat menjadi salah satu unsur terbentuknya suatu negara dan rakyatlah yang menjalankan HAM, dan dalam hal ini ilmu sosiologi adalah ilmu yang mempelajari terkait dengan hubungan antar masyarakat satu dengan yang lain baik dari segi masyarakat sebagai komponen Negara maupun manusia sebagai seorang warga negara. Selain itu perkembangan pembelajaran dalam Pendidikan Kewarganegaraan juga dapat merujuk pada sebab-sebab terjadinya penyimpangan yang terjadi pada masyarakat di Indonesia dewasa ini. Penyimpangan sosial yang mana adalah perilaku yang tidak sesuai dengan nilai-nilai

\footnotetext{
8 Keputusan Direktur Jenderal Pendidikan Tinggi Departemen Pendidikan Nasional Republik Indonesia No.43 Tahun 2006, tentang Rambu-rambu Pelaksanaan Kelompok Mata Kuliah Pengembangan Kepribadian di Perguruan Tinggi, Pasal 3 ayat (2) huruf $b$.

${ }^{9}$ Soerjono Soekanto: J.S. Roucek, Pengendalian Sosial (Jakarta:CV Rajawali, 1987) hlm.20

${ }^{10} \mathrm{Ibid} . \mathrm{hlm} .21$
} 
kesusilaan atau kepatutan, baik dalam sudut pandang kemanusiaan (agama) secara individu maupun pembenarannya, sebagai bagian dari makhluk sosial.

Berdasarkan uraian tersebut maka dapat disimpulkan bahwa hubungan antara kedua disiplin ilmu tersebut sangat erat karena sudah jelas bahwa Sosiologi mempelajari tentang kehidupan sosial atau kemasyarakatan dalam hal interaksi, Pendidikan Kewarganegaraan mempelajari bagaimana masyarakat menaati peraturan-peraturan untuk menjadi warga negara yang baik, untuk membawa masyarakat kearah kehidupan bersama yang harmonis. Tentu sangat berkaitan karena interaksi sosial yang ini dapat tewujud dengan cara menaati peraturan.

Selanjutnya, perkembangan Pendidikan Kewarganegaraan juga mengacu pada ilmu sejarah, sekalipun bukan merupakan bagian dari ilmu sejarah. Dalam ilmu sejarah terdapat kaitan atau hubungan yang erat dengan Pendidikan Kewarganegaraan, ibarat tidak ada masa depan kalau tidak ada masa lalu (sejarah) begitu juga ilmu Pendidikan Kewarganegaraan yang tidak mungkin lahir Ilmu Pendidikan Kewarganegaraan jika tidak ada sebab dan akibat (sejarah). Dalam hal ini Pendidikan Kewarganegaraan yang membahas mengenai kewarganegaraan yang mana menyangkut dengan Negara dan munculnya suatu negara berhubungan dengan sejarah oleh karena itu sejarah mempunyai hubungan terhadap ilmu Pendidikan Kewarganegaraan.

Pembahasan berlanjut pada perkembangan Pendidikan Kewarganegaraan dengan ilmu politik, dimana ilmu politik merukan rumpun dari ilmu sosial humaniora yang membahas terkait dengan kekuasaan dan kekuasaan pasti berhubungan dengan organisasi yang mana negara juga termasuk dalam sebuah organisasi dunia. Pendidikan Kewarganegaraan mempelajari mengenai kewarganegaraan dalam arti luas mempelajari mengenai Warga (rakyat) dan Negara, dalam kasus ini ilmu politik mempuyai hubungan dengan Pendidikan Kewarganegaraan yang mana politik dengan kekuasaannya memimpin suatu organisasi yang bernama Negara dan warga (rakyat) lah yang menjadi tujuan dan sumber di bentuknya suatu Negara tersebut.

Pendidikan Kewarganegaraan dalam perkembangannya juga melibatkan Ilmu Hukum yang secara spesifikasi di maksudkan adalah Hukum Pidana, Hukum Acara, Hukum Adat, Hukum Perkawinan, Hukum Agraria yang mana inti dari Hukum tersebut adalah sangsi (Hukuman) yang mana dalam Pendidikan Kewarganegaraan yang mempelajari sebuah Negara dan negara juga pasti terbentuk dengan bermodalkan aturan-aturan yang berbentuk hukum sebagai landasan Negaranya, oleh karena itu Pendidikan Kewarganegaraan berhubungan dengan Ilmu hukum yang mana Pendidikan Kewarganegaraan sebagai bentuk Negaranya dan Ilmu Hukum sebagai aturannya.

Selain itu terdapat perspektif mengenai Pendidikan Kewarganegaraan dalam ilmu sosial yang berkaitan dengan Sosial-Politik Indonesia yakni terkait dengan pengaturan, kondisi, serta ideologi. Pengaturan sosial-politik dalam arti yang luas, meyangkut konsep pemerintahan dan kenegaraan yang berlangsung secara formal dan yang tidak formal. Secara formal, pengaturan tersebut berlangsung pada tingkat pemerintah dan negara mulai dari pemerintahan pusat sampai ke daerah. Sedangkan pengaturan yang tidak formal, berlangsung di dalam keluarga atau di dalam marga dan pada suku-suku bangsa tertentu. Pengaturan sosial-politik ini telah berlangsung sejak manusia mulai berkelompok dan bermasyarakat. 
Kondisi sosial-politik selama penjajahan Belanda dan masa pendudukan Jepang sedikit banyak masih berpengaruh dalam kehidupan Bangsa Indonesia saat ini. Setidaktidaknya pada kelompok masyarakat yang secara langsung terlibat dalam kehidupan pemerintahan dan kenegaraan saat itu. Pranata-pranata sosial-politik pada masa penjajahan Belanda yang lampau, harus kita akui masih banyak kita gunakan. Pranata tadi, selama tidak bertentangan dengan cita-cita sosial-politik Bangsa Indonesia secara selektif masih dapat kita manfaatkan. Hanya dalam hal ini tentu saja selanjutnya kita harus mampu menciptakan sendiri pranata sosial-politik yang paling cocok dengan kehidupan bangsa Indonesia. Dalam hal ini, sudah tidak dapat ditawar lagi, yang paling cocok dengan cita-cita sosial-politik Pancasila.

Ideologi yang diartikan sebagai "suatu pandangan atau sistem nilai yang menyeluruh dan mendalam yang dipunyai dan dipegang oleh suatu masyarakat tentang bagaimana cara yang sebaiknya, yaitu secara moral dianggap benar dan adil, mengatur tingkah laku bersama dalam berbagai segi kehidupan duniawi”, harus kita miliki. Ideologi yang demikian sifatnya itu telah kita miliki bersama yaitu Ideologi Pancasila. Pancasila inilah yang menjadi Ideologi untuk mengatur segala segi kehidupan Bangsa Indonesia secara baik dan bermoral. Cita-cita sosial politik dan ideologi Pancasila inilah yang harus kita terapkan untuk menjawab tantangan dan masalah yang secara praktis kita hadapi dewasa ini ${ }^{11}$.

Menurut R.Barr, dalam citizenship transmission tradition, nilai-nilai tertentu yang dipandang sebagai "nilai-nilai yang baik" ditanamkan dalam upaya untuk mengajari peserta didik guna menjadi warga negara yang baik. Komponen yang teramat penting dari nilai tersebut ialah bagaimana supaya peserta didik dapat menerapkan nilai-nilai tersebut secara rasional dan kritis (critical thinking), atau dengan inquiri khususnya diantara temantemannya. Namun demikian pertimbangan-pertimbanngan rasional dan kritis tidaklah memadai tanpa didukung oleh pertimbangan keimanan (beliefs), dan sikap (attitudes). Dalam tradisi pendidikan di Indonesia, Ilmu Pengetahuan Sosial sebagai pewarisan nilai-nilai kewarganegaraan lebih banyak dilakukan oleh mata kuliah Pendidikan Kewarganegaraan. Namun demikian, bukan berarti Ilmu Pengetahuan Sosial di negara kita tidak memiliki perspektif tersebut, tetapi peran perspektif tersebut lebih dominan berada dalam kuliah Pendidikan Kewarganegaraan.

\section{PENUTUP}

Kehidupan sosial masyarakat senantiasa mengalami perubahan dari waktu ke waktu. Perubahan tersebut dapat dilihat baik dalam konteks keruangan (tempat tinggal) maupun konteks waktu. Perkembangan kehidupan masyarakat yang ditandai dengan pesatnya kemajuan teknologi dan informasi pada pihak yang lain telah memunculkan berbagai ketimpangan moral, akhlak, social-ekonomi, politik dan jati diri bangsa, termasuk di dalamnya penyimpangan nilai dan etika serta pelangaran HAM dalam kehidupan berbangsa dan bernegara. Pendidikan kewarganegaraan sebenarnya dikembangkan diseluruh dunia, meskipun dalam pelaksanaanya terdapat beberapa perubahan nama yang digunakan. Namun perbedaan nama tersebut tidak mengurangi esesnsi dari maksud dan tujuannya yaitu

\footnotetext{
${ }^{11}$ Nursing Sumaatmadja, Perspektif Studi Sosial (Bandung: Penerbit Alumni, 1986) hlm.42-45.
} 
menegarakan Negara itu. Ilmu ini memiliki peran yang sangat penting dalam mempersiapkan warga Negara yang penuh dengan tanggung-jawab dan rasa nasionalisme yang tinggi. Berdasarkan rumusan civic international (1995) disepakati bahwa pendidikan demokrasi penting untuk pertumbuhan civic culture.

Tidak berbeda dengan ilmu pendidikan lainnya, ilmu pendidikan kewarganegaran juga mempunyai objek yaitu materil dan formil. Dalam filsafat ilmu Pendidikan Kewarganegaraan dimana filsafat yang menjadi induk dalam ilmu pengetahuan, yang mana Pendidikan Kewarganegaraan merupakan ilmu yang berada di bagian ilmu pengetahuan sosial dan kedudukan Pendidikan Kewarganegaraan sangat berpengaruh terhadap sikap dan mental bangsa Indonesia karena di dalam Pendidikan Kewarganegaraan mengajarkan nilainilai pancasila yang sekaligus Pancasila itu sebagai dasar dari Negara Indonesia dan mengembangkannya di dalam kehidupan bermasyarakat. Sama dengan ilmu pendidikan lainnya, ilmu pendidikan kewarganegaraan juga memiliki sisi kelebihan dan juga kelemahan, di sini kita sebagai mahasiswa Pendidikan Kewarganegaraan yang memiliki andil besar dalam mengatasi kelemahan-kelemahan Pendidikan Kewarganegaraan dan mengembangkan kelebihan Pendidikan Kewarganegaraan agar dapat menjadi lebih baik.

Kemudian terkait dengan perkembangan mata kuliah Pendidikan Kewarganegaraan dalam rumpun ilmu sosial, maka mata kuliah dalam Ilmu Sosial diajarkan sebagai pewaris dari nilai Kewarganegaraan (Citizenship Transmission). Ilmu Sosial sebagai pewarisan nilainilai kewarganegaraan tujuan utamanya adalah mempersiapkan anak didik menjadi warga negara yang baik. Nilai dan budaya bangsa akan dijadikan landasan untuk pengembangan bangsanya. Setiap bangsa atau negara mendidik warganya berdasarkan nilai dan budaya yang dimilikinya. Seorang pendidik harus mempersiapkan anak didiknya dengan nilai-nilai demokrasi Pancasila yang dapat dilaksanakan dalam kehidupan sehari-hari. Jadi, dalam kaitan transformasi nilai-nilai kewarganegaraan tujuan dari mata kuliah dalam Ilmu Sosial adalah menjadikan anak didik menjadi warga negara Indonesia yang baik.

\section{DAFTAR PUSTAKA}

Branson, M. S. (1999). Belajar "Civic Education" dari Amerika (Terjemahan Syarifudin dkk). Yogyakarta: LKIS

Djahiri, A. Kosasih. (2006). Pendidikan Nilai Moral dalam Dimensi Pendidikan Kewarganegaraan. Bandung: FPIPS-UPI

Djahiri, Achmad Kosasih. (2006), Esensi Pendidikan Nilai-Moral dan PKN di Era Globalisasi, Bandung: Lab PKn UPI.

Handhaa, Resti. (2014). Kedudukan PKn dalam Perspektif Ilmu [online]. Tersedia di: http://restyhandhaaa.blogspot.com/2014/01/kedudukan-pkn-dalam-prespektifilmu_1.html.

Soekanto, Soerjono (1987). J.S. Roucek: Pengendalian Sosial. Jakarta : CV. Rajawali.

Sumaatmadja, Nursid. Dr. (1986). Perspektif Studi Sosial. Bandung: Penerbit Alumni

Undang-Undang Republik Indonesia Nomor 20 Tahun 2003 tentang Sistem Pendidikan Nasional (UU Sisdiknas). 
Wahab, Abdul Aziz dan Sapriya. (2011). Teori dan Landasan Pendidikan Kewarganegaraan. Bandung: Alfabeta.

Winataputra, U.S. (2014). Diskursus Aktual Tentang Paradigma Pendidikan Kewarganegaraan (PKn) Dalam Konteks Kurikulum 2013. Bahan Diskusi dalam Semnas PKn-AP3KnI. 